\title{
Electrifying Roller-Coaster Ride through Speed Breakers
}

\author{
Amod Kumar Pandey \\ SRMSWCET, Dept. of EC \\ Bareilly, India
}

\author{
Somya Yadav \\ SRMSWCET, Dept. of EC \\ Bareilly, India
}

\author{
Tanu Srivastava \\ SRMSWCET, Dept. of EC \\ Bareilly, India
}

\begin{abstract}
This is a electronics based researchpaper on electricity generation through speed breakers. This project produces energy from speed breakers by making use of roller arrangement and electronic circuits.Large amount of energy can be generated through this method.It will prove beneficial to the government if implemented.It is based on the principle of conversion of potential energy to kinetic energy and finally into electrical energy. There are three mechanisms to generate electricity through speed breakers viz., Rack \& Pinion mechanism,Crank Shaft mechanism, Roller mechanism.In this paper Roller Mechanism is being explained.
\end{abstract}

\section{General Terms}

electricity generation, quick production of electricity.

\section{Keywords}

dc: direct current, ac: alternating current, generation, dynamo, transmission

\section{INTRODUCTION}

In this modern era electricity has become one of the basic amenities for survival. Man is totally dependent on electronics nowadays. Consumption of electricity in India is growing day by day and there are very less resources to meet the demands of the people because consumption is very much greater than the supply.

Some of the highlights of the current power production status in India:

- India's current installed capacity (end of 2010): $1,70,229 \mathrm{MW}$, from all sources

- Power generation capacity is mainly based on thermal and hydro, with about $11 \%$ from renewable energy.

- In 2010, peak power shortage was $12 \%$.

- Electricity demand is expected to rise by $7.4 \%$.

According to Central Electricity Authority(CEA) by the year 2008 India's electricity demand was $124 \mathrm{GW}$ out of which only $96 \mathrm{GW}$ could be supplied. So, alternative methods need to be incorporated to meet the electricity demands and also to lighten up the burden on non- renewable resources.

The idea to generate electricity through speed breakers can bring a renaissance in field of power consumption. TheGovernment will also be able to cope up with the energy crisis as this method is economic and easy to implement.

\section{MECHANISM}

As the vehicle moves over the roller the gear arrangement attached to the roller comes into motion. The rotation of larger gear attachedto the roller causes the smaller gear to rotate. One rotation of the larger gear is equal to five rotations of the smaller gear.

The smaller gear of the gear arrangement is attached to the dynamo. The dynamo here is used to convert the rotational energy into electrical energy.

A rectifier circuitry is being used to convert ac into dc. The electrical energy is then stored into the battery which is connected to the inverter circuitry.

Finally through this arrangement we can obtain a maximum of $15 \mathrm{~W}$ power supply.

\section{EXPERIMENTAL SETUP}

An iron roller is fixed on a wooden ramp on which vehicle passes. As vehicle passes over it, itstarts moving. A gear arrangement is provided which transfers the motion to a dynamo for the generation of electricity, as in Fig 1.

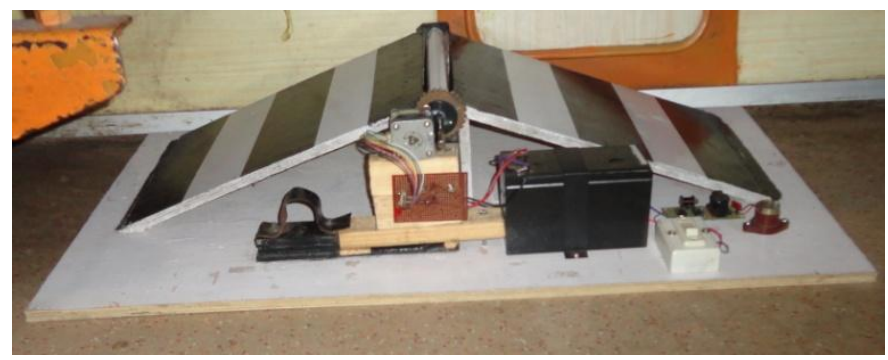

Fig 1: Experimental Setup

\section{EQUIPMENTS USED \\ 4.1 Gear Arrangement}

A gear arrangement is a rotating machine part having cut teeth or sprockets with one gear resting or moving over the other gear in order to transmit torque. Two or more gears can work in tandem. Such gear system is known as transmitting gearsand can produce a mechanical advantage through a gear ratio and thus may be considered a simple machine. Geared devices can also be used along with a non-rotating toothed part called rack thereby producing translation instead of rotation.

\subsection{Battery}

It is used for the storage of electrical energy generated by the dynamo. Here we have used dry cell battery. Dry cell batteries are those that have electrolyte in a paste form and have just enough moisture for the current to pass. 


\subsection{Rectifier}

A rectifier is one which removes the ac ripples from dc output. It is employed in this project to enhance the efficiency of the system.Rectifiers have many uses, but are often found serving as components of DC power suppliesand high-voltage direct currentpower transmission systems.

\subsection{Dynamo}

A dynamo is an electromechanical device that converts electrical energy to mechanical energy in the form of alternating current. In principle, a dynamo is used to convert ac into dc through a commutator. Most dynamos use a rotating magnetic field with a stationary armature. Occasionally, a rotating armature is used with a stationary magnetic field. See fig 2 .

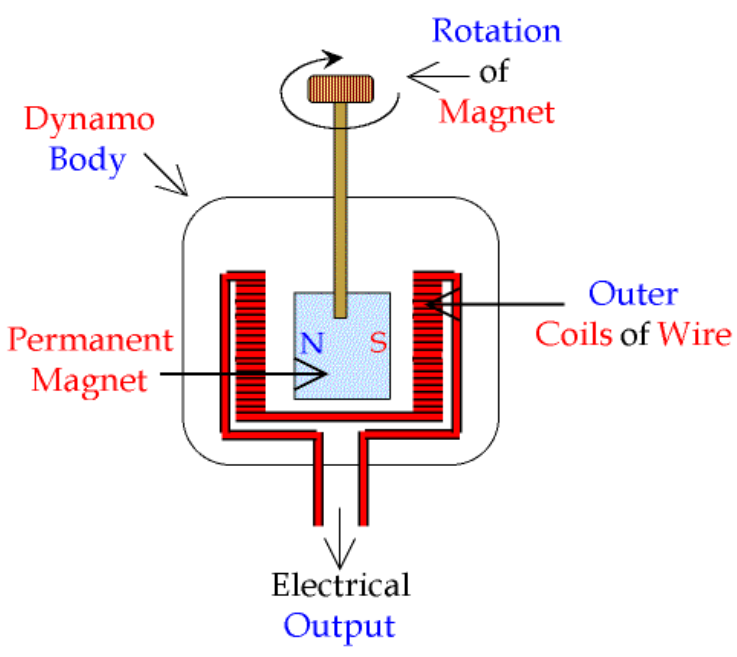

Fig 2: Dynamo

\subsection{LED}

Light emitting diode (LED) is basically a P-N junction semiconductor diode particularly designed to emit visible light. The LEDs are made in the form of flat tiny P-N junction enclosed in a semi-spherical dome-like case made up of clear coloured epoxy resin. The dome of a LED acts as a lens and diffuser of light.

\subsection{Inverter}

It is used to convert dc into ac. The converted ac can be at any required voltage and frequency with the use of appropriate transformers, switching, and control circuits. The inverter performs opposite function of the rectifier.

\subsection{Transformer}

A transformer is a static electrical device that operates on the principle of Faraday's Law of Electromagnetic Induction. It consists of two windings: primary and secondary. Here a stepup transformer is used.

Table 1. Specifications of Wooden Ramp

\begin{tabular}{|c|c|c|}
\hline Sr. No. & Parts & Dimensions(mm) \\
\hline 1 & Wooden Board & $480 * 250$ \\
\hline 2 & Platform & $245 * 120$ \\
\hline 3 & $\begin{array}{c}\text { Thickness of } \\
\text { Board }\end{array}$ & 18 \\
\hline
\end{tabular}

Table 2. Specifications of Metal Roller

\begin{tabular}{|c|c|c|}
\hline S. No. & \multicolumn{1}{c|}{ Parts } & Dimensions(mm) \\
\hline 1 & $\begin{array}{c}\text { Outside diameter } \\
\text { of roller }\end{array}$ & 140 \\
\hline 2 & $\begin{array}{c}\text { Inside diameter of } \\
\text { roller }\end{array}$ & 130 \\
\hline 3 & Length of roller & 305 \\
\hline 4 & Diameter of shaft & 30 \\
\hline
\end{tabular}

\section{BLOCK DIAGRAM}

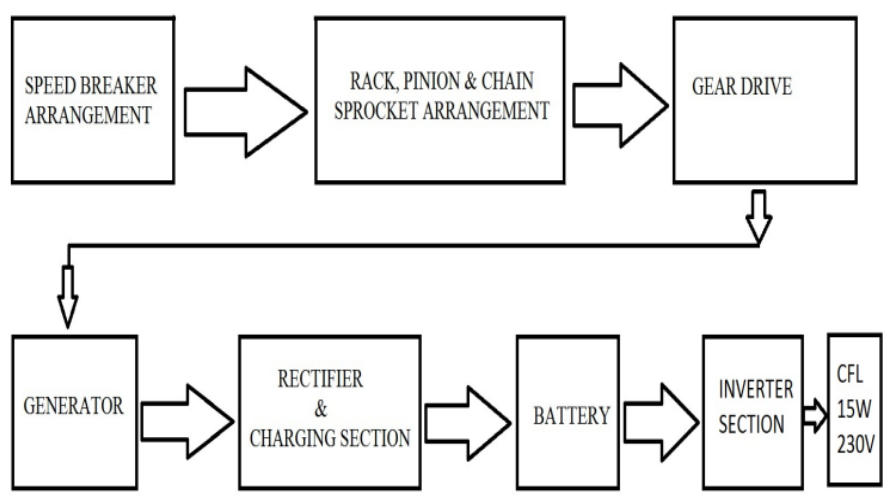

Fig 3: Block Diagram of Generation of Electricity from Speed Breakers

\section{MATHEMATICAL MODELLING}

$\omega_{1}=$ Angular Speed of Vehicle Tire $(\mathrm{rad} / \mathrm{sec})$

$\omega_{2}=$ Angular Speed of Roller $(\mathrm{rad} / \mathrm{sec})$

$\mathrm{d}_{1}=$ Diameter of Tire $(\mathrm{mm})$

$\mathrm{d}_{2}=$ Diameter of Roller $(\mathrm{mm})$

$\mathrm{v}=$ Velocity of Vehicle $(\mathrm{m} / \mathrm{sec})$

$\mathrm{r}=$ Radius of wheel $(\mathrm{mm})$

$\mathrm{I}=$ Moment of Inertia of Roller (pipe)

$\mathrm{d}_{\mathrm{o}}=$ Outside Diameter of Roller $(\mathrm{mm})$

$\mathrm{d}_{\mathrm{i}}=$ Inside Diameter of Roller $(\mathrm{mm})$

$\mathrm{V}=$ Voltage (volts)

$\mathrm{I}=$ Current (Ampere)

$\mathrm{T}=$ Time (seconds)

R = Rotational Kinetic Energy of Roller (Joules)

$\mathrm{E}=$ Electrical Energy (Joules)

And,

Linear velocity, $v=r * \omega$

Moment of Inertia of Roller, $I=\left(\Pi *\left(4\left(d_{0}-d_{1}\right)\right)\right) / 64$ 
Rotational Kinetic Energy of Roller, $\mathrm{R}=\left(\mathrm{I}^{*}\left(\omega_{2}\right)^{2}\right) / 2$

Electrical energy, $E=V * I * T$.

Efficiency, $\eta=E / R$

Table 3. Summary of Experiments Carried out on Electrical Apparatus

\begin{tabular}{|c|c|c|c|c|c|c|}
\hline $\begin{array}{l}\text { S.N } \\
\text { o. }\end{array}$ & $\begin{array}{l}\text { Rotationa } \\
\text { l Kinetic } \\
\text { Energy of } \\
\text { Roller(J) }\end{array}$ & $\begin{array}{l}\text { Vol( } \\
\text { V) }\end{array}$ & $\begin{array}{l}\text { Curr } \\
\text { ent( } \\
\text { A) }\end{array}$ & $\begin{array}{l}\text { Tim } \\
\text { e(sec } \\
\text { ) }\end{array}$ & $\begin{array}{l}\text { Electrical } \\
\text { Energy }(\mathbf{J})\end{array}$ & $\begin{array}{l}\text { Effi } \\
\text { cien } \\
\text { cy }\end{array}$ \\
\hline 1 & 4541 & 5 & 0.8 & 4 & 16 & 0.4 \\
\hline 2 & 6469 & 5.5 & 1 & 4 & 22 & $\begin{array}{l}0.4 \\
5\end{array}$ \\
\hline 3 & 10057 & 6.4 & 1.2 & 4 & 31 & $\begin{array}{l}0.4 \\
8\end{array}$ \\
\hline
\end{tabular}

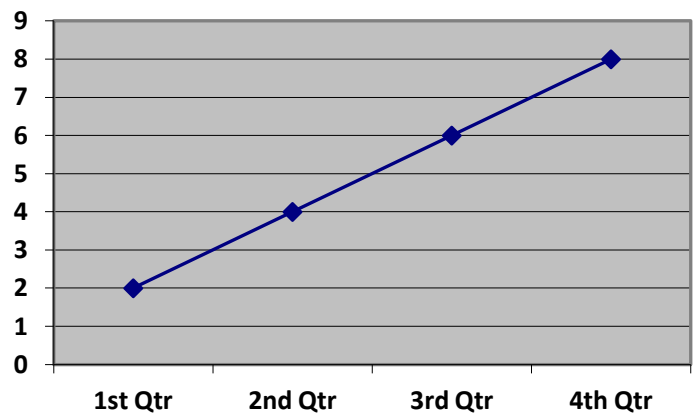

Fig 4: Graph of energy versus velocity

\section{CONCLUSION}

This project will prove a great boon to the world as it serves the need of the hour i.e. electricity. It will specially be good for the developing countries which are suffering with energycrisis. The simple approach of the project can be used to harness immense amount of electricity. For countries like India where rural development is still not at its pace, this idea is of utmost worth. It can be used for power supply into the remote areas, lighting the street lamps. It can be well employed on highways and the energy thus stored can be utilized in several ways.

This project has some advantages which are:-

The project is economical and easy to install.

This project is non polluting.

Maintenance cost is low.

Installation cost is low.
This project has certain disadvantages also such as:

- Rain water may cause damage to the components.

\section{FUTURE ENHANCEMENT}

There are certain enhancements which may lead to the efficiency of the project \& will also help in improving rate of power generation. Following are some enhancements:

- Increasing the number of rollers can generate upto 1000W electricity.

- Using sprocket arrangement will produce $100 \mathrm{~W}$ of power.

- If the same arrangement is used on the next side of the roller then with the help of this setup power of $500 \mathrm{~W}$ can be created.

\section{ACKNOWLEDGEMENT}

We take this opportunity to express our profound gratitude and deep regards to our guide Amod Kumar Pandeyfor his exemplary guidance, monitoring and constant encouragement throughout the course of this research paper. The blessing, help and guidance given by him time to time shall carry us a long way in the journey of life on which we are about to embark. We also take this opportunity to express a deep sense of gratitude to Ms.NaziaParveen, Head of E.C. Department for her cordial support, valuable information and guidance, which helped us in completing this task through various stages. Lastly, we thank Almighty, our parents and friends for their constantencouragement without which this assignment would not be possible.

\section{REFERENCES}

[1] Annamalai Arunachalam, Eco-friendly Electricity generation: Electricity from speed-breakers, India, 2011.

[2] Awasthaman.V\&Priyadarshini.M, Every Speed Breaker is Now a Source of Power, IPCBEE vol.1, Singapore, 2011.

[3] P.M. Anderson and A.AFouad.Power System Control and Stability.

[4] Mohsen Artodezfoli, AbbasRezaey, Zahra Baniasad, Horieh Rezaey, A Novel Speed Breaker for Electrical Energy Generation Suitable for Elimination of Remote Parts of Power Systems where is Near to Roads,Text Road Publications, 2012.

[5] M.D. Singh \& K. Khan Chandani, Power Electronics, Tata McGraw Hill 1998 Edition

[6] M H Rashid, Power Electronics, $3^{\text {rd }}$ Ed., Pearson Education, 2009.

[7] B. G. Streetman and S. Banerjee, Solid state electronics devices, 5th Edition, PHI. 